\title{
The vegetation of three localities of the threatened butterfly species Chrysoritis aureus (Lepidoptera: Lycaenidae)
}

\author{
R.F. Terblanche, T.L. Morgenthal and S.S. Cilliers
}

Terblanche, R.F., T.L. Morgenthal and S.S. Cilliers. 2003. The vegetation of three localities of the threatened butterfly species Chrysoritis aureus (Lepidoptera: Lycaenidae). Koedoe 46(1): 73-90. Pretoria. ISSN 0075-6458.

The vegetation and habitat characteristics of three localities of Chrysoritis aureus at the Alice Glockner Nature Reserve, Suikerbosrand Nature Reserve and Malanskraal farm near Heidelberg in South Africa, were compared. A numerical classification technique, TWINSPAN, was used and refined by using Braun Blanquet procedures to classify the vegetation at the different localities. A DCA ordination was applied to confirm the results of the classification. Although the general vegetation structure at the three habitats of Chrysoritis aureus were found to be similar, marked differences in the floristic composition were evidenced. A different sub-community, compared to the vegetation at Suikerbosrand and Alice Glockner Nature Reserve, was recorded at the Malanskraal habitat of Chrysoritis aureus. These differences in floristic composition, but with similarities in vegetation structure, indicate the possible importance of fire for the ultimate survival of these butterflies in the Rocky Highveld Grassland. The host plant of Chrysoritis aureus, Clutia pulchella, collected at Malanskraal differed markedly and consistently in their morphology, compared to the individuals from the habitats at Suikerbosrand and Alice Glockner Nature Reserve. These differences in the floristic composition of one of the habitats compared to the others, raise research questions concerning the butterfly metapopulation structure, since the subpopulations seem to be adapted to slightly different habitat conditions. The variation in the habitat suggests that the "last remaining locality scenario" for other localised butterflies in South Africa, such as Orachrysops niobe, needs to be redressed. Management strategies are addressed while the importance of conserving rare, localised ecosystems are highlighted by the phytosociological study.

Key words: myrmecophilous, Lycaenidae, Chrysoritis, Clutia, Crematogaster, habitat, phytosociology, conservation

R.F. Terblanche (drkrft@puknet.puk.ac.za), T.L. Morgenthal \& S.S. Cilliers, School of Environmental Sciences and Development, Private Bag X6001, Potchefstroom University for CHE, Potchefstroom, 2520 Republic of South Africa.

\section{Introduction}

The butterfly Chrysoritis aureus-previously known as Poecilmitis aureus before the new combination was designated by Heath (1997) - is considered to be Rare in the Red Data book of butterflies (Henning \& Henning 1989) and the updated list of the Red Data book of butterfly species (Henning \& Henning 1995). C.R. Barrett and F. Coetzee discovered Chrysoritis aureus on Christmas Day 1959 on a rocky slope below the water tower near the Natal road of Heidelberg in Gauteng (Pringle et al. 1994). During 1983, Chrysoritis aureus was added to the protected wild animal list of the former Transvaal under Ordinance 12, since the type locality had been the only known area where the butterfly ocurred (De Wet 1987). G.A. Henning found another locality near Greylingstad (Pringle et al. 1994). Members of the Lepidopterists' Society of Africa found another locality in Suikerbosrand Nature Reserve (Henning \& Henning 1989) after teams of 


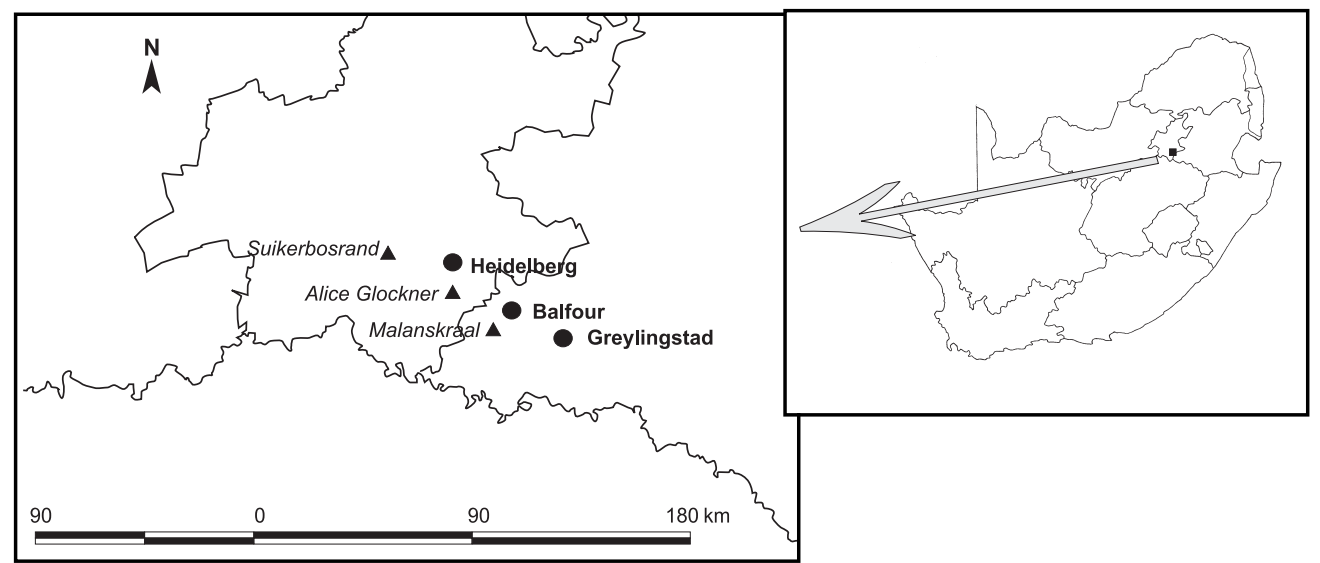

Fig. 1 The location of the habitats of Chrysoritis aureus that were studied.

lepidopterists carried out organised extensive exploration in this reserve (Fig. 1). The colony at Suikerbosrand seems to be limited in numbers (Henning \& Henning 1989; Roos \& Henning 2000) though the numbers tend to remain stable (The word 'colony' refers to the subpopulations of these butterflies, that is where they actually breed. The adults usually also fly at or close to these restricted areas). In the Suikerbosrand Nature Reserve, the only recorded habitat of the butterfly is limited to the north eastern extreme of the reserve, even though the Lepidopterists's Society of Africa organised surveys that covered many different habitats in the reserve (G.A. Henning 1986a, 1986b, 1987). After decades of exploring by a number of lepidopterists in the hilly areas of Gauteng and the adjacent Mpumalanga (Table 1), only five confirmed localities of Chrysoritis aureus were reported. The distribution of the butterfly can be described as patchy and

Table 1

The locality, altitude and geological system present at the confirmed localities of Chrysoritis aureus

\begin{tabular}{llll} 
Locality & Province & Altitude (m) & $\begin{array}{r}\text { Geological } \\
\text { Supergroup }\end{array}$ \\
\hline
\end{tabular}

Alice Glockner NR

$8 \mathrm{~km} \mathrm{~S}$ Heidelberg

Gauteng $26^{\circ} 34^{\prime} \mathrm{S}, 28^{\circ} 22^{\prime} \mathrm{E}(2628 \mathrm{CB})$

1690

Witwatersrand

Hill N of Greylingstad

Mpumalanga $26^{\circ} 44^{\prime} \mathrm{S}, 28^{\circ} 44^{\prime} \mathrm{E}(2628 \mathrm{DA})$

1810

Ventersdorp

Malanskraal locality

14 km W Balfour

Mpumalanga $26^{\circ} 39^{\prime} \mathrm{S}, 28^{\circ} 26^{\prime} \mathrm{E}(2628 \mathrm{CB})$

1780

Ventersdorp

Suikerbosrand NR

Gauteng $\quad 26^{\circ} 29^{\prime} \mathrm{S}, 28^{\circ} 18^{\prime} \mathrm{E}(2628 \mathrm{AD})$

1720

Witwatersrand

Type locality

at Heidelberg

Gauteng $26^{\circ} 29^{\prime} \mathrm{S}, 28^{\circ} 21^{\prime} \mathrm{E}(2628 \mathrm{AD})$

1600

Witwatersrand

* The grid reference reading is from the north western corner of each minute by minute square.

**The Malanskraal locality is close to the borderline between the Ventersdorp supergroup and the

Witwatersrand Supergroup. 
Chrysoritis aureus is very localised at each of these localities. The three habitats studied each cover approximately $200 \mathrm{~m}^{2}-400 \mathrm{~m}^{2}$.

All the recorded localities of Chrysoritis aureus are situated at sites where formal or informal urban development pose an everincreasing threat to the habitat. Habitat destruction across the world as the main cause for the extinction of populations of localised butterflies, is well recognised, thereby emphasising the primary importance of habitat conservation (S.F. Henning 1987; Larsen 1995; Kudrna 1995; Munguira 1995; New 1995; Oates 1995; Opler 1995; Pullin et al. 1995; Thomas 1995; Warren 1995). An ongoing comparative study of the Chrysoritis aureus habitats (vegetation) is therefore imperative to gain knowledge for developing strategies for the conservation of these habitats. A description of the vegetation of the Chrysoritis aureus habitats is needed if management practices such as translocation of butterflies or habitat restoration is considered. Vegetation studies of the habitats of the threatened Golden Sun Moth in Australia (O’Dwyer \& Attiwill 2000), provided essential information for the restoration of its habitat. A vegetation analysis of the then only known habitat of a threatened butterfly, Aloeides dentatis subsp. dentatis, in South Africa, (Deutschländer \& Bredenkamp 1999) was very applicable for its conservation management. For this study, the vegetation of three habitats were compared to identify possible key factors and to detect possible differences between these habitats.

This study also forms part of an ongoing investigation into the reasons why the subpopulations of the butterfly are confined to such small areas. In South Africa, studies on myrmecophilous butterflies, such as Chrysoritis aureus, are limited to life history descriptions or reporting of information on the host plant and host ant. Some clues for the confinement of Chrysoritis aureus to its habitats can be found in its life history (Henning 1983). The host plant of the larvae is the small shrub Clutia pulchella L. Sens. lat. (Euphorbiaceae) which is widely distributed in South Africa (Arnold \& De Wet

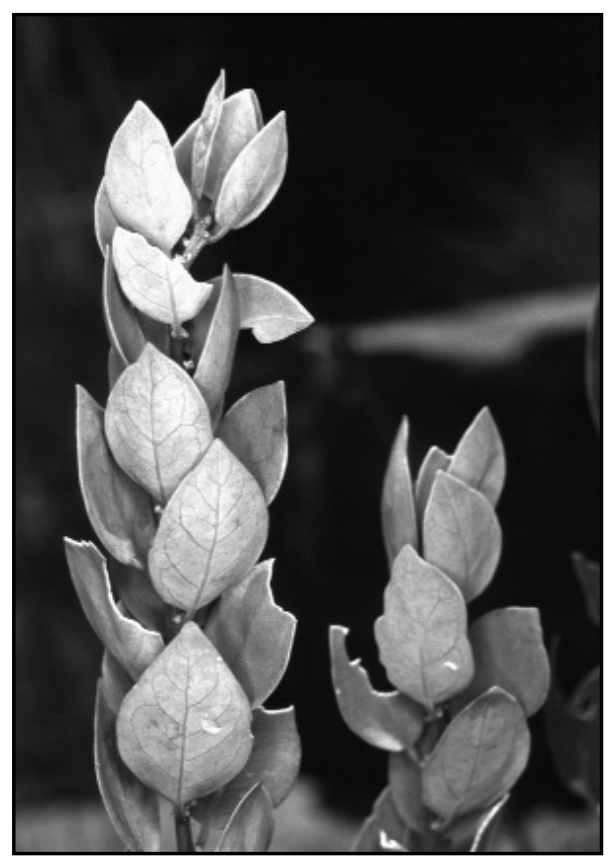

Fig. 2. Clutia pulchella ("Heidelberg morphotype"), the host plant of Chrysoritis aureus.

1993; Retief \& Herman 1997) (Fig. 2). The larvae of Chrysoritis aureus are also constantly tended by ants of the genus Crematogaster (Henning 1983). During the day, the larvae shelter for protection and only appear at night to feed on their host plants (Henning 1987a). Well developed dorsal nectary organs (Cottrell 1984) or honey glands (Henning 1983 ; 1987a) are present on the larvae and the ants are attracted to feed on the secretions of these organs (Henning 1983, 1987a). In the absence of the ants, a fungal infection occurs in the dorsal nectary organ and the larvae often die after a few days (Henning 1983) (Fig. 3). Since both the ant and the host plant are needed for survival of Chrysoritis aureus at any locality, the habitat requirements are complicated. These include specific local vegetation communities. We therefore investigated the vegetation, to con- 


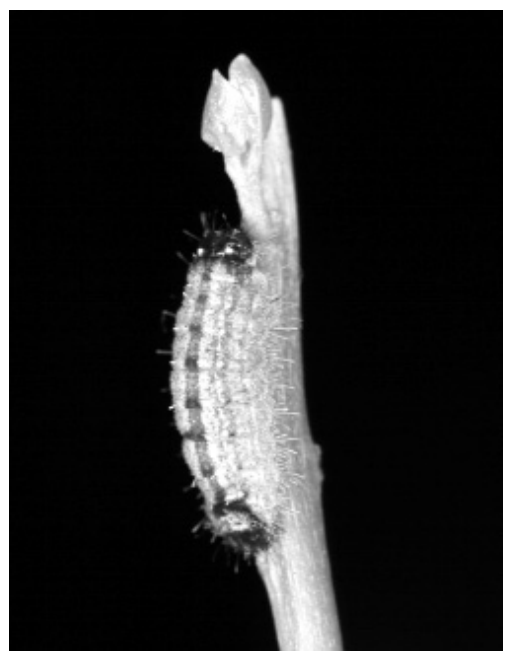

Fig. 3. The larva of Chrysoritis aureus. The two white structures at the anterior (head) area, are tubercle organs. Note the fungal growth at the posterior end at the dorsal nectary organ. Photo: R.F. Terblanche.

tribute to a niche/habitat profile of Chrysoritis aureus.

\section{Study area}

Three localities inhabited by Chrysoritis aureus were studied: one at the Suikerbosrand Nature Reserve, one at the Alice Glockner Nature Reserve near Heidelberg, Gauteng and one at the farm Malanskraal (Fig. 1). The habitats of Chrysoritis aureus are situated on the south-facing slopes of rocky ridges and hills. The first two habitats studied are situated on the quartzites of the Wiwatersrand Supergroup while the habitat at Malanskraal habitat is situated on the lavas of the Ventersdorp Supergroup. The landscape is rugged and broken in appearance, since the Witwatersrand System was subjected to considerable folding, faulting and erosion in the past (Du Toit 1954).

The study sites are in the summer rainfall area, with temperate summers and cold frosty winters. According to information obtained from the South African Weather Service, the long-term average annual rainfall data from nearby weather stations vary considerably between $620-750 \mathrm{~mm}$ per annum (South African Weather Service, Private Bag X097, Pretoria, 0001). Variation in topography, the rock cover and vegetation structure results in different meso- and microclimates.

The sites that were investigated are situated in the Grassland Biome (Rutherford \& Westfall 1994; Low \& Rebelo 1996), the Bankenveld (Acocks 1988) or Rocky Highveld Grassland (Bredenkamp \& Van Rooyen 1996).

\section{Materials and methods}

Sample plots $(5 \mathrm{~m} \times 5 \mathrm{~m})$ were placed on the habitats of Chrysoritis aureus. These plots fitted well on the restricted habitats of Chrysoritis aureus at the Alice Glockner Nature Reserve and Malanskraal, while four sample plots were adequate for the habitat at Suikerbosrand. Since the range of occurence of Chrysoritis aureus is so small, the samples are thought to be representative. A transect of sample plots over the habitat from the summit to the midslopes and down to a valley bottom, was surveyed at the Alice Glockner Nature Reserve to compare the vegetation on the slopes close to the habitats with the habitats of Chrysoritis aureus (Fig. 4). The floristic composition and cover abundance according to the Braun-Blanquet scale (Mueller-Dombois \& Ellenberg 1974) were noted in each plot during surveys on 12 and 13 February 1999. The number of Clutia pulchella individuals that occurred in each sample plot were determined. Plant specimens were deposited in the A.P. Goossens Herbarium of the Potchefstroom University for C.H.E. The height of trees (Von Breitenbach 1990; Von Breitenbach et al. 2001) was noted. These species will, therefore, be referred to as trees, even if they are physionomically not regarded as trees. The height classes as described by Edwards (1983) were used. Habitat features such as slope, aspect and rockiness were noted, though not quantitatively measured. Notes on the presence of Chrysoritis aureus and other butterflies were continuously made by means of direct observations on 7 and 13 November, 1998 as well as 12 and 13 February 1999. The local distribution of Chrysoritis aureus was confirmed by P. Roos and G.A. Henning who have visited the localities for a 


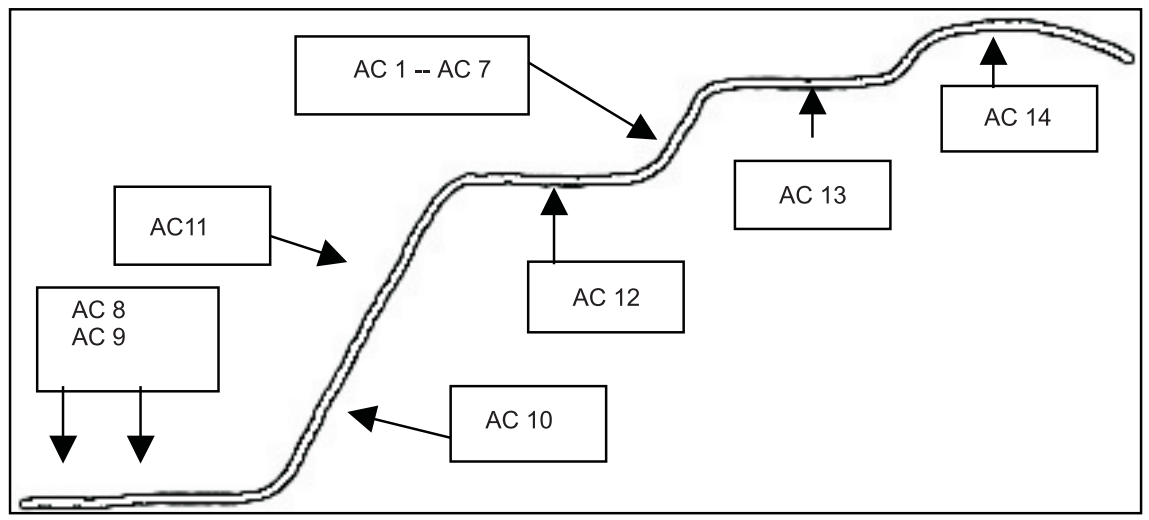

Fig. 4. Position of the $5 \mathrm{~m} \times 5 \mathrm{~m}$ sample plots from the summit (AC 14) to the lower valley bottom (AC 8, AC 9) of the hill (southern aspect) at Alice Glockner Nature Reserve. The seven plots (AC 1-AC 7) that are inhabited by Chrysoritis aureus were put out horizontally next to each other along the rocky ridge.

number of years (Roos \& Henning 2000). The same procedure was also followed for the breeding sites, i.e., where pupae, larvae, and oviposition by the female were evidenced. The ants associated with Chrysoritis aureus have been identified by Dr. H.G. Robertson, South African Museum, Cape Town, 8000 .

The TWINSPAN classification algorithm (Hill 1979a) was used to analyse the floristic data and the result was refined by using Braun Blanquet procedures by means of the BBPC-suite (Bezuidenhout et al. 1996). A DCA ordination was applied (Hill 1979b) to confirm the results of the classification.

\section{Results and discussion}

\section{The host plant}

Mr. I. Bampton discovered the host plant of Chrysoritis aureus in January 1976 (OwenJohnston 1991). It is sometimes reported to be Clutia galpinii (Owen-Johnston 1991; Heath 2001). Clutia galpinii is considered to be a synonym of Clutia pulchella (Retief \& Herman 1997). The entity Clutia galpinii refers to a relatively smaller plant of $91 \mathrm{~cm}-$ $152 \mathrm{~cm}$, whereas Clutia pulchella reaches heights up to $244 \mathrm{~cm}$ (Prain 1925). Clutia pulchella individuals that have been measured near or at the habitats of Chrysoritis aureus, ranged from $13 \mathrm{~cm}$ to more than $200 \mathrm{~cm}$ tall (in more dense vegetation) and fits the descriptions of both entities overviewed by Prain (1925). The plant specimens from the localities of Chrysoritis aureus were compared to the material at the National Herbarium. It does not fit Clutia monticola of which the leaves are sessile (Retief \& Herman 1997). The host plant of Chrysoritis aureus was confirmed to be only Clutia pulchella at all the localities.

Clutia pulchella constantly showed specific variation from different localities. Individuals from Malanskraal have more lanceolate leaves, are of a less bluish-green colour and the upper surface of the leaves are covered with velvety hairs. This is in contrast to the more ovate, more glaucous and much less hairy leaves of individuals from the Alice Glockner Nature Reserve and Suikerbosrand Nature Reserve. The reasons for these differences could be due to the different geological systems where these plants occur. These morphotypes may be the subject of more detailed study on the taxonomic status of the host plant. Larvae of the different localities 
Table 2

The number of Clutia pulchella counted as well as the status of Chrysoritis aureus at the plots $(5 \mathrm{~m} \times 5 \mathrm{~m})$

\begin{tabular}{lcc}
\hline $\begin{array}{l}\text { Plot } \\
\text { number }\end{array}$ & $\begin{array}{c}\text { Number of } \\
\text { Clutia pulchella } \\
\text { individuals }\end{array}$ & $\begin{array}{c}\text { Status of } \\
\text { C. aureus } \\
1=\text { present } \\
0=\text { absent }\end{array}$ \\
\hline AC 1 & 4 & 1 \\
AC 2 & 3 & 1 \\
AC 3 & 4 & 1 \\
AC 4 & 7 & 1 \\
AC 5 & 13 & 1 \\
AC 6 & 14 & 1 \\
AC 7 & 2 & 1 \\
AC 8 & 0 & 0 \\
AC 9 & 0 & 0 \\
AC 10 & 5 & 0 \\
AC 11 & 4 & 0 \\
AC 12 & 0 & 0 \\
AC 13 & 0 & 0 \\
AC 14 & 2 & 0 \\
MK 15 & 7 & 1 \\
MK 16 & 8 & 1 \\
MK 17 & 10 & 1 \\
SB 18 & 6 & 1 \\
SB 19 & 10 & 1 \\
SB 20 & 8 & 1 \\
SB 21 & 13 & \\
\hline
\end{tabular}

seems to be adapted to feed on these different morphotypes of Clutia pulchella.

The number of Clutia pulchella individuals at the sample plots where Chrysoritis aureus is present varies (2-14 indiv/ $\left.25 \mathrm{~m}^{2}\right)$ with an average of 7.8 individuals $/ 25 \mathrm{~m}^{2}$ for all the habitats combined - that means an average of 0.31 Clutia pulchella indiv $/ \mathrm{m}^{2}$. The locality at the Alice Glockner Nature Reserve showed the lowest average of Clutia pulchella individuals namely 6.7 indiv $/ 25 \mathrm{~m}^{2}$. Though Chrysoritis aureus was not present at sample plots AC 10, AC 11 and AC 14, host plant individuals were recorded at these sites. The number of host plants at sample plots AC 10 and AC 11 (Table 2) seems to be adequate to serve as possible breeding areas. All the sites where Clutia pulchella individ- uals were present are characterised by the presence of large rocks and this seems to be one of the key habitat requirements of the host plant. The factors that can play a role in excluding Chrysoritis aureus from establishing at sample plots $\mathrm{AC} 10$ and $\mathrm{AC} 11$, are not known. However, both sample plots AC 10 and $\mathrm{AC} 11$ are situated on the lower midslopes compared to the other sites where Clutia pulchella occurs at higher midslopes in the Alice Glockner Nature Reserve (Fig. 4).

Another subject for further research is the local distribution and vitality of Clutia pulchella in the vicinity of Chrysoritis aureus habitats. It was observed that Clutia pulchella may have higher densities and seemed to have better vitality (higher plants) in some of the surrounding areas, where no plots were put out, as Chrysoritis aureus was not present here. A quantitative survey may shed more light on the above observation.

\section{Vegetation classification}

The floristic composition of the plant communities identified is represented in a phytosociological table (Table 3 ) and the results of the DCA-ordination (Fig. 5). The phytosociological analysis resulted in the following two communities with their sub-communities and variants:

1. Melinis nerviglumis-Aristida transvaalensis Community

1.1. Melinis nerviglumis-Aristida transvaalensis-Eragrostis curvula Subcommunity

1.2 Melinis nerviglumis-Aristida transvaalensis-Loudetia simplex Sub-community

1.2.1. Anthospermum hispidulum Variant

1.2.2 Digitaria monodactyla Variant

1.3. Melinis nerviglumis-Aristida transvaalensis-Englerophytum magalismontanum Sub-community

2. Elionurus muticus-Eragrostis trichophora Community 


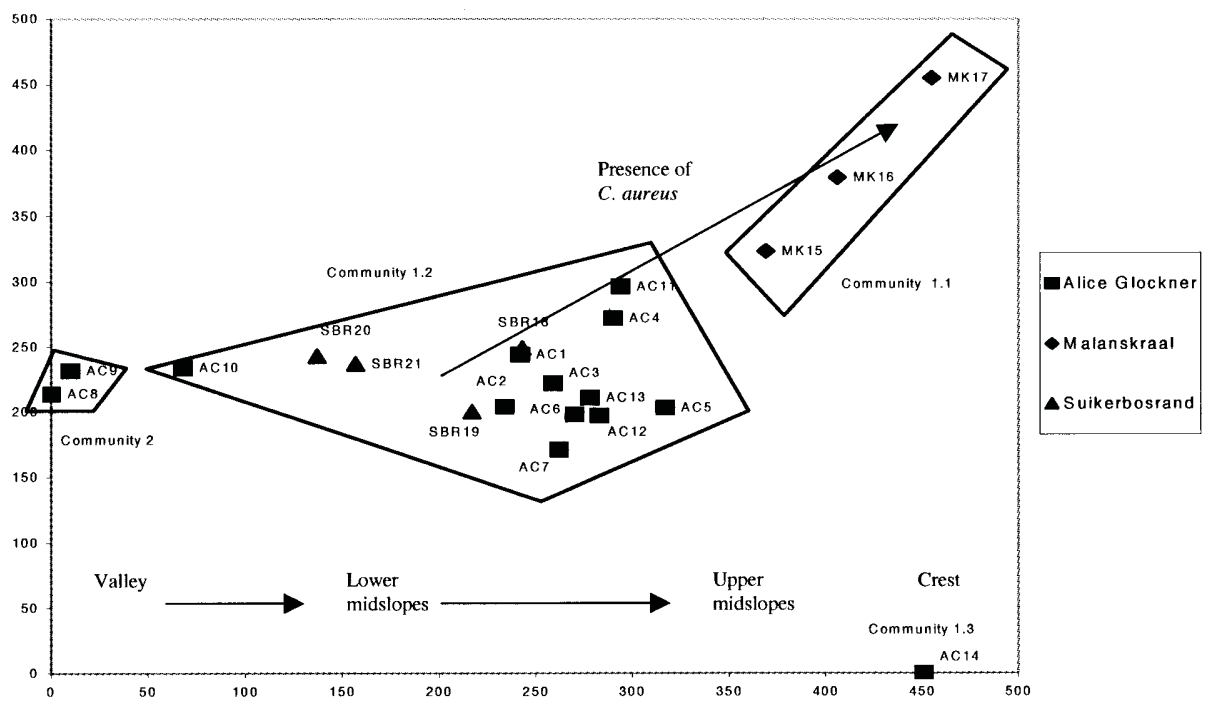

Fig. 5. DCA-ordination of the sample plots at the Alice Glockner Nature Reserve (AC), Malanskraal (MK) and Suikerbosrand Nature Reserve (SBR).

\section{Community description}

\section{Melinis nerviglumis - Aristida transvaalensis Community}

This community is found on the south-facing slopes and on the terraces within the slopes, and includes a representation of all the habitats of Chrysoritis aureus that were studied. Apart from the terraces, large rocks (often exceeding one metre in length) are conspicuous on all the sites. The community is characterised and dominated by the grasses Melinis nerviglumis, Aristida transvaalensis and Cymbopogon plurinodis (Species group A, Table 3). Three subcommunities are recognised:

\subsection{Melinis nerviglumis-Aristida trans- vaalensis -Eragrostis curvula Sub- community}

This sub-community occurs on the southfacing slopes at Malanskraal on the Venters- dorp Supergroup (Table 1). It is characterised by the absence of Loudetia simplex and the constant high cover-abundance values of Eragrostis curvula, Helichrysum nudifolium and the constant presence of Garuleum pinnatifidum and Tephrosia capensis (Species group B, Table 3). This sub-community is further characterised by a number of plant species with a low constancy which are exclusive to this subcommunity. These include the forbs Calpurnia glabrata, Pelargonium sidoides and the dwarf shrub Rhus discolor. Three tree species, namely Leucosidea sericea, Buddleja salviifolia and Gymnosporia buxifolia were recorded in this sub-community with a low cover-abundance and constancy. None of these tree species exceeded $2 \mathrm{~m}$ in height and therefore the woody layer is represented only by shrubs lower than $2 \mathrm{~m}$. The Malanskraal habitat of Chrysoritis aureus is also the exclusive habitat to this sub-community. 
Table 3

A phytosociological table of the surveys done at the Alice Glockner Nature Reserve, Malanskraal and Suikerbosrand

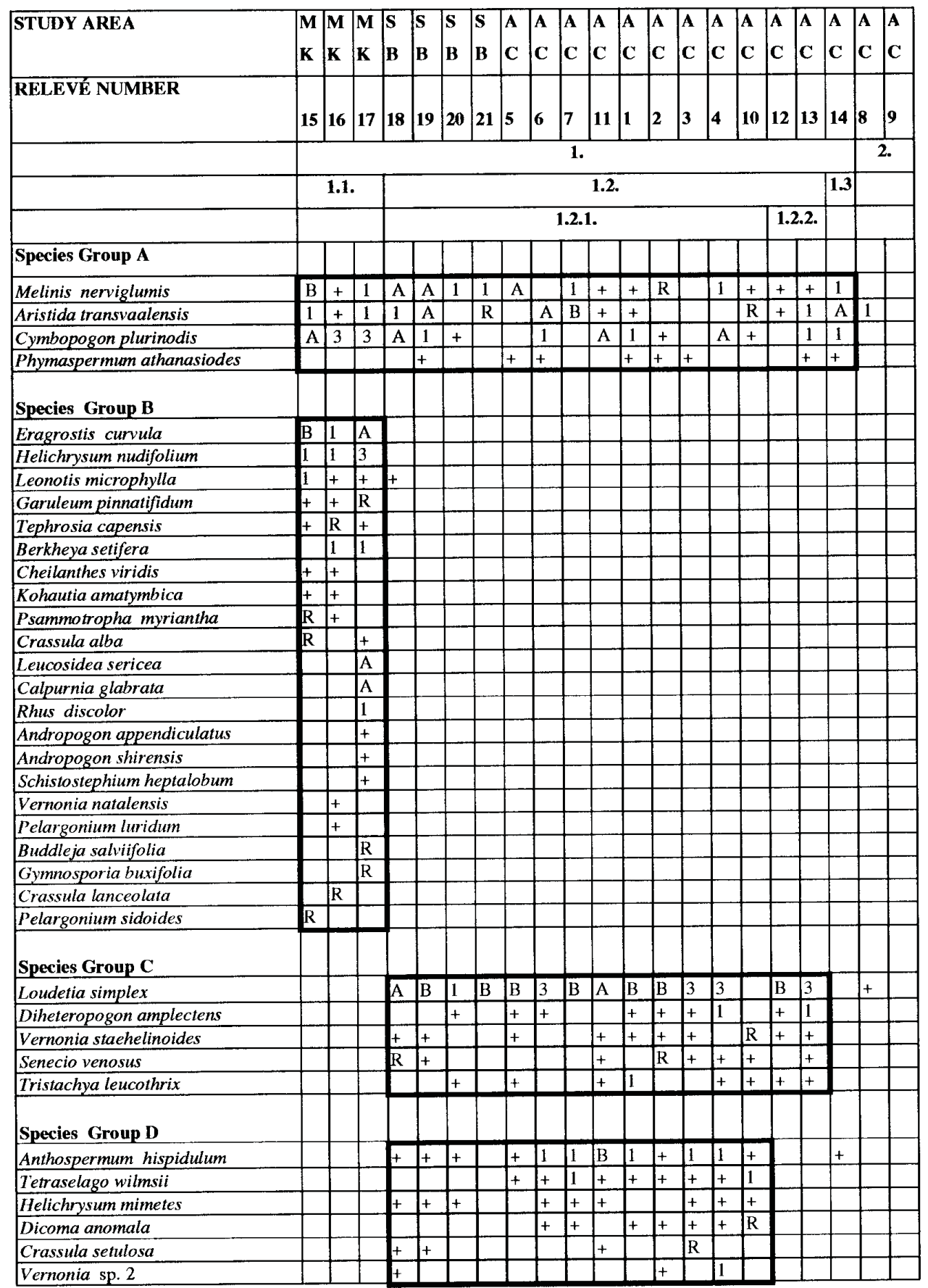


Table 3

(continued)

\begin{tabular}{|c|c|c|c|c|c|c|c|c|c|c|c|c|c|c|c|c|c|c|c|c|c|}
\hline STUDYY AREA & $\begin{array}{l}\mathbf{M} \\
\mathbf{K}\end{array}$ & $\begin{array}{l}\mathbf{M} \\
\mathbf{K}\end{array}$ & $\begin{array}{l}\mathbf{M} \\
\mathbf{K}\end{array}$ & $\begin{array}{l}\text { S } \\
\text { B }\end{array}$ & \begin{tabular}{|l|}
$\mathbf{S}$ \\
$\mathrm{B}$
\end{tabular} & \begin{tabular}{|l|}
$\mathbf{S}$ \\
$\mathbf{B}$
\end{tabular} & $\begin{array}{l}\mathbf{S} \\
\mathbf{B}\end{array}$ & \begin{tabular}{|l|}
$\mathbf{A}$ \\
$\mathbf{C}$
\end{tabular} & \begin{tabular}{l|}
$\Lambda$ \\
$\mathbf{C}$
\end{tabular} & \begin{tabular}{|l|}
$\mathbf{A}$ \\
$\mathbf{C}$
\end{tabular} & \begin{tabular}{|l|}
$\mathbf{A}$ \\
$\mathrm{C}$
\end{tabular} & \begin{tabular}{|l|}
$\mathbf{A}$ \\
$\mathbf{C}$
\end{tabular} & \begin{tabular}{|l|l|}
$\mathbf{A}$ & \\
\end{tabular} & $\begin{array}{l}\mathbf{A} \\
\mathbf{C}\end{array}$ & \begin{tabular}{|l|}
$\mathbf{A}$ \\
$\mathbf{C}$
\end{tabular} & \begin{tabular}{|l|}
$\mathbf{A}$ \\
$\mathbf{C}$
\end{tabular} & $\begin{array}{l}\mathbf{A} \\
\mathbf{C}\end{array}$ & \begin{tabular}{|l|}
$\mathbf{A}$ \\
$\mathrm{C}$
\end{tabular} & & $\begin{array}{l}\mathbf{A} \\
\mathrm{C}\end{array}$ & $\begin{array}{l}\mathbf{A} \\
\mathrm{C}\end{array}$ \\
\hline RELEVÉ NUMBER & 15 & 16 & 17 & 18 & 19 & 20 & 21 & 5 & 6 & 7 & 11 & 1 & 2 & 3 & 4 & 10 & 12 & 13 & & 8 & 9 \\
\hline & & & & & & & & & & 1. & & & & & & & & & & 2. & 2. \\
\hline & & 1.1. & & & & & & & & & 1.2. & & & & & & & & 1.3 & & \\
\hline & & & & & & & & & & 1.2.1 & & & & & & & & 2.2. & & & \\
\hline Species Group E & & & & & & & & & & & & & & & & & & & & & \\
\hline Digitaria monodactyla & 1 & A & & & & & & & & & & & & & & & A & 1 & & & 1 \\
\hline Aristida aequiglumis & & & & & & & & & & & & & & & & & $\mathrm{A}$ & + & & & \\
\hline Ursinia nana & & & & & & & & & & 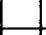 & & & & & & & 1 & & & & 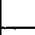 \\
\hline Cyperus rupestris & & & & & & & & & & . & & & & & & & 1 & . & 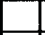 & & 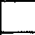 \\
\hline Schizachyrium sanguineum & & & & & & & & & & & & & & & & & + & + & & & 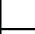 \\
\hline Berkheya zeyheri & & & & & & & & & & & & & & & & & + & & - & & - \\
\hline Anthospermum rigidum & & & & & & & & & & & & & & & & & + & & & & \\
\hline Polygala uncinata & & & & & & & & & & & & & & & & & & + & & & \\
\hline Sporobolus pectinatus & & & & & & & & & & & & & & & & & & + & 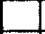 & & 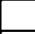 \\
\hline Dianthus mooiensis & & & & & & & & & & & & & & & & & E & $\mathrm{R}$ & & & 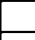 \\
\hline Species Group F & & & & & & & & & & & & & & & & & & & & & \\
\hline Englerophytum magalismon & & & & & & & & & & & & & & & & & & & $\mathrm{B}$ & & \\
\hline Ancylobotrys capensis & & & & & & & & & & & & & & & $\mathrm{R}$ & & & & B & & \\
\hline Species Group G & & & & & & & & & & & & & & & & & & & & & \\
\hline Elionurus muticus & & & & & & & & & & & & & & & & & & & & B & A \\
\hline Eragrostis trichophora & & & & & & & & & & & & & & & & & & & & $\mathrm{B}$ & $\mathrm{A}$ \\
\hline Indigofera comosa & & & & & & & & & & & & & & & & & & & & B & 1 \\
\hline Digitaria tricholaenoides & & & & & & & & & & & & & & & & & & & & $\mathrm{A}$ & + \\
\hline Heteropogon contortus & & & & & & & & & & & & & & & 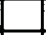 & & & & & + & + \\
\hline Setaria sphacelata & & & & & & & & & & . & & & & & 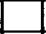 & & & & & 1 & \\
\hline Vernonia oligocephala & & & & & & & & & & & & & & & & & & & & - & 1 \\
\hline Eragrostis chloromelas & & & & & & & & & & & & & & & & & & & & L & + \\
\hline Hyparrhenia hirta & & & & & & & & & & & & & & & & & & & & - & + \\
\hline Acrotome hispida & & & & & & & & & & & & & & & & & & & & + & \\
\hline Commelina africana & & & & & & & & & & . & & & & & 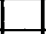 & & 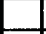 & & & + & \\
\hline Commelina sp. & & & & & & & & & & & & & & & & & & & & + & \\
\hline Senecio affinis & & & & & & & & & & & & & & & & & & & & + & \\
\hline Pentanisia angustifolia & & & & & & & & & & & & & & & & & & & & $\mathbf{R}$ & \\
\hline Striga asiatica & & & & & & & & & & & & & & & 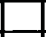 & & & & & & $\mathbf{R}$ \\
\hline Trichoneura grandiglumis & & & & & & & & & & & & & & & & & & & & & $\mathbf{R}$ \\
\hline Stoebe vulgaris & & $1+$ & & & & & & & & & & & & & & & & & & & $R$ \\
\hline
\end{tabular}




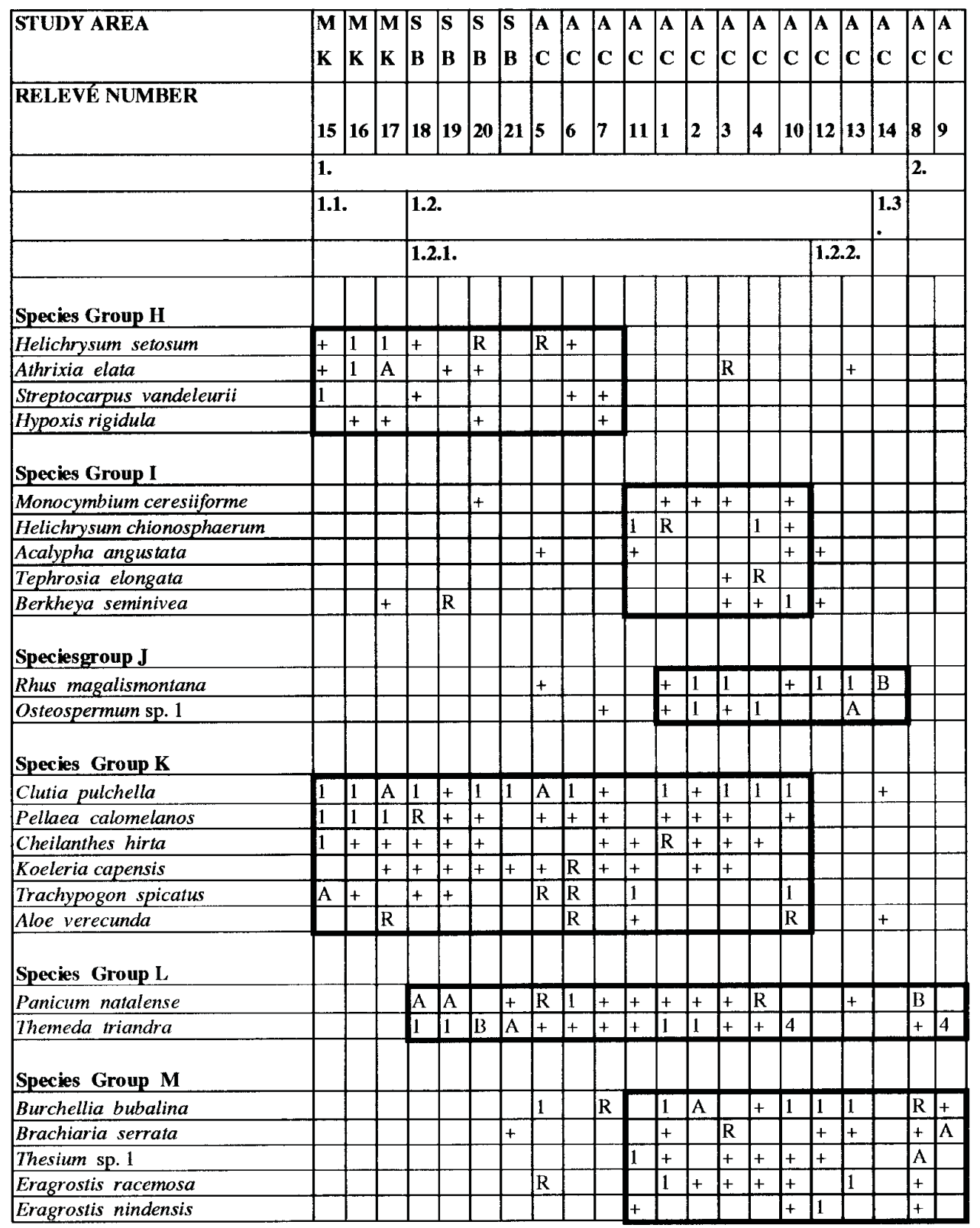




\begin{tabular}{|l|l|l|l|l|l|l|l|l|l|l|l|l|l|l|l|l|l|l|l|l|l|}
\hline STUDY AREA & $\mathbf{M}$ & $\mathbf{M}$ & $\mathbf{M}$ & $\mathbf{S}$ & $\mathbf{S}$ & $\mathbf{S}$ & $\mathbf{S}$ & $\mathbf{A}$ & $\mathbf{A}$ & $\mathbf{A}$ & $\mathbf{A}$ & $\mathbf{A}$ & $\mathbf{A}$ & $\mathbf{A}$ & $\mathbf{A}$ & $\mathbf{A}$ & $\mathbf{A}$ & $\mathbf{A}$ & $\mathbf{A}$ & $\mathbf{A}$ & $\mathbf{A}$ \\
& $\mathbf{K}$ & $\mathbf{K}$ & $\mathbf{K}$ & $\mathbf{B}$ & $\mathbf{B}$ & $\mathbf{B}$ & $\mathbf{B}$ & $\mathbf{C}$ & $\mathbf{C}$ & $\mathbf{C}$ & $\mathbf{C}$ & $\mathbf{C}$ & $\mathbf{C}$ & $\mathbf{C}$ & $\mathbf{C}$ & $\mathbf{C}$ & $\mathbf{C}$ & $\mathbf{C}$ & $\mathbf{C}$ & $\mathbf{C}$ & $\mathbf{C}$ \\
\hline
\end{tabular}

1.2. Melinis nerviglumis-Aristida transvaalensis-Loudetia simplex Sub-community

This sub-community was recorded on the quartzite slopes of Alice Glockner and Suikerbosrand on the Witwatersrand Supergroup (Table 1). The diagnostic species include the grasses Loudetia simplex, Diheteropogon amplectens, Tristachya leucothrix and the forbs Vernonia staehelinoides and Senecio venosus. (Species group C, Table 3 ). It is interesting to note that the forbs Vernonia staehelinoides and Senecio venosus (Species group C, Table 3) are absent from the sites of all the other communities, but are found scattered throughout this community. This community can be divided into two variants:

\subsubsection{Anthospermum hispidulum Variant}

This variant is recorded from the southfacing rocky slopes of the Alice Glockner Nature Reserve and the Suikerbosrand Nature Reserve. The constant presence of Anthospermum hispidulum characterises this variant while Clutia pulchella occurs abundantly on most of the sites that were surveyed in this community. The bracken fern Pteridium aquilinum was only found at the Suiker- 
bosrand habitat (Table 3) which at first glance gave the Suikerbosrand habitat a different appearance. The similarities with the habitats at Alice Glockner Nature Reserve were only revealed after the vegetation classification. Almost no tree species were found at all these sites. The woody layer is represented by Canthium gilfillanii, Myrsine africana and Diospyros lyciodes subsp. guerkei (Table 3). These woody species occurred sporadically, had low cover-abundance values, and none were taller than $1 \mathrm{~m}$. Chrysoritis aureus occurs on most of these sites, excluding sites AC 10 and $\mathrm{AC} 11$ that are present on the lower midslopes (Fig..4). Of interest is that Chrysoritis lycegenes, a closely related species of Chrysoritis aureus, uses Myrsine africana as host plant (Henning 1983). Chrysoritis lycegenes, however, is mainly restricted to central Kwa-Zulu Natal and the eastern Free State.

\subsubsection{Digitaria monodactyla Variant}

This variant was observed on two flat terraces on the slopes at Alice Glockner Nature Reserve (Fig. 4). The diagnostic species include the grasses Aristida aequiglumis, Digitaria monodatyla and Schizachyrium sanguineum (Table 3, Species Group E). The terraces are narrow and form a mini-plateau, whereas the huge exposed rocks that occur elsewhere on the slopes are absent. Chrysoritis aureus does not colonise these flat terraces, and this coincides with the absence of the host plant Clutia pulchella (Table 2, Table 3).

\subsection{Melinis nerviglumis-Aristida trans- vaalensis-Englerophytum magalis- montanum Sub-community}

The summit of the ridge at the Alice Glockner Nature Reserve is the habitat of this subcommunity which is dominated by shrubs rather than grasses and forbs. A small patch of vegetation, measuring only approximately $10 \mathrm{~m} \times 10 \mathrm{~m}$, which differs physiognomically from the surrounding areas, is present. The diagnostic species is the shrub Englerophytum magalismontanum. Other dominant shrubs present are Myrsine africana, Ancylobotrys capensis and Rhus magalismontana. No Chrysoritis aureus occur at this site since the habitat is not suitable. A number of other butterflies namely Coeliades forestan, Junonia archesia, Junonia oenone, Cigaritis natalensis and Anthene butleri subsp. livida showed typical hilltopping behaviour at this site. Hilltopping indicates a type of territorial behaviour where males of butterfly species gather at tops of hills, often at midday-individuals will choose a site which they will defend by flying after "intruders". No hilltopping of Chrysoritis aureus was observed.

\section{Elionurus muticus - Eragrostis trichophora Community.}

This community is found in the valley bottom on the southern hillside below the rocky ridges at the Alice Glockner Nature Reserve. It is characterised by the diagnostic species namely the grasses Elionurus muticus, Eragrostis trichophora, Digitaria tricholaenoides and Heteropogon contortus as well as the forbs Indigofera comosa and Vernonia oligocephala (Species Group G, Table 3). Very little exposed rocks occur in this area and the plant species cover abundance is relatively higher than in all the other sample plots. Chrysoritis aureus is absent in this community.

\section{DCA-ordination}

The results of the DCA-ordination (Fig. 4) support the classification of the communities identified from the phytosociological table. The difference between the floristic composition of the habitats of Chrysoritis aureus at Malanskraal and those at Suikerbosrand Nature Reserve and Alice Glockner Nature Reserve, is confirmed by the results of the DCA ordination - a topographical gradient from the valley bottom to the upper slopes are reflected by the configuration of the ordination. The position of the sample plots on ordination axis two can be related to the geology, with habitats on the Ventersdorp Lava Supergroup at the top and habitats on 
the Witwatersrand Supergroup in the middle and at the bottom. The discontinuous position of AC 14 on the scatter diagram may partly be due to its location on the summit of a ridge in contrast with all the other sample plots that are on south-facing slopes.

The Elionurus muticus-Eragrostis trichophora community is at the left extreme along ordination axis 1 of the scatter diagram and the Melinis nerviglumis-Aristida transvaalensis community (Community 1.1., 1.2 and 1.3) to the middle and right of the scatter diagram. The Melinis nerviglumis-Aristida transvaalensis-Eragrostis curvula subcommunity (Community 2) that occurs at Malanskraal is situated at the top right end of the DCA scatter diagram and the Melinis nerviglumis-Aristida transvaalensis-Loudetia simplex sub-community in the middle.
Most of the sample plots, of which the plant species composition, geology and topography favour the presence of Chrysoritis aureus, are to the middle-right and top end of the scatter diagram. This confirms the importance of open vegetation on south-facing rocky upper slopes for the survival of the butterfly.

\section{Discussion}

\section{The habitat of Chrysoritis aureus}

Table 4 provides a matrix in which some of the important environmental habitat characteristics that became apparent in this study, are listed. The altitude at the investigated habitats varies between $1690 \mathrm{~m}-1780 \mathrm{~m}$,

Table 4

A table with specified habitat factors/ observations that apply to a relevé $(=1)$ or not $(=0)$. If a number 1 is in bold it indicates that the presence of Chrysoritis aureus coincides with the factor. The presence of Chrysoritis aureus is indicated in the first row of the matrix

\begin{tabular}{|c|c|c|c|c|c|c|c|c|c|c|c|c|c|c|c|c|c|c|c|c|c|}
\hline DESCRIPTION & $\begin{array}{l}\mathbf{M} \\
\mathbf{K}\end{array}$ & $\begin{array}{l}\mathbf{M} \\
\mathbf{K}\end{array}$ & $\begin{array}{l}\mathbf{M} \\
\mathbf{K}\end{array}$ & $\begin{array}{l}\mathbf{S} \\
\mathbf{B}\end{array}$ & $\begin{array}{l}\mathbf{S} \\
\mathbf{B}\end{array}$ & $\begin{array}{l}\mathbf{S} \\
\mathbf{B}\end{array}$ & $\begin{array}{l}\text { S } \\
\text { B }\end{array}$ & $\begin{array}{l}\mathbf{A} \\
\mathbf{C}\end{array}$ & $\begin{array}{l}\mathrm{A} \\
\mathrm{C}\end{array}$ & $\begin{array}{l}\mathbf{A} \\
\mathbf{C}\end{array}$ & $\begin{array}{l}\mathbf{A} \\
\mathbf{C}\end{array}$ & $\overline{\mathbf{A C}}$ & $\begin{array}{l}\mathrm{A} \\
\mathrm{C}\end{array}$ & $\begin{array}{l}\bar{A} \\
\mathrm{C}\end{array}$ & $\begin{array}{l}\mathbf{A} \\
\mathbf{C}\end{array}$ & $\begin{array}{l}\mathbf{A} \\
\mathbf{C}\end{array}$ & $\begin{array}{l}\mathrm{A} \\
\mathrm{C}\end{array}$ & $\begin{array}{l}\mathrm{A} \\
\mathrm{C}\end{array}$ & $\begin{array}{l}\mathbf{A} \\
\mathrm{C}\end{array}$ & $\begin{array}{l}\mathbf{A} \\
\mathbf{C}\end{array}$ & $\begin{array}{l}\mathbf{A} \\
\mathbf{C}\end{array}$ \\
\hline RELEVE NUMBER & $\begin{array}{l}1 \\
5\end{array}$ & 1 & $\begin{array}{l}1 \\
7\end{array}$ & $\begin{array}{l}1 \\
8\end{array}$ & $\begin{array}{l}1 \\
9\end{array}$ & $\begin{array}{l}2 \\
0\end{array}$ & $\begin{array}{l}2 \\
1\end{array}$ & 5 & 6 & 7 & $\begin{array}{l}1 \\
1\end{array}$ & 1 & 2 & 3 & 4 & $\begin{array}{l}1 \\
0\end{array}$ & $\begin{array}{l}1 \\
2\end{array}$ & $\begin{array}{l}1 \\
3\end{array}$ & $\begin{array}{l}1 \\
4\end{array}$ & 8 & 9 \\
\hline & & & & & & & & & 1 & & & & & & & & & & & & 2. \\
\hline & & 1.1 . & & & & & & & & & 2. & & & & & & & & 1. & & \\
\hline & & & & & & & & & & .1. & & & & & & & 1.2 & .2. & & & \\
\hline $\begin{array}{l}\text { Presence of } \\
\text { Chrysoritis aureus }\end{array}$ & 1 & 1 & 1 & 1 & 1 & 1 & 1 & 1 & 1 & 1 & 0 & 1 & 1 & 1 & 1 & 0 & 0 & 0 & 0 & 0 & 0 \\
\hline $\begin{array}{l}\text { Altitude between } \\
1600 \mathrm{~m}-1810 \mathrm{~m}\end{array}$ & 1 & 1 & 1 & 1 & 1 & 1 & 1 & 1 & 1 & 1 & 1 & 1 & 1 & 1 & 1 & 1 & 1 & 1 & 1 & 1 & 1 \\
\hline $\begin{array}{l}\text { Aspect: } \\
\text { Southern slope }\end{array}$ & 1 & 1 & 1 & 1 & 1 & 1 & 1 & 1 & 1 & 1 & 1 & 1 & 1 & 1 & 1 & 1 & 1 & 1 & 0 & 1 & 1 \\
\hline $\begin{array}{l}\text { Upper } \\
\text { midslopes }\end{array}$ & 1 & 1 & 1 & $\mathbf{1}$ & 1 & 1 & 1 & 1 & 1 & 1 & 0 & 1 & 1 & 1 & 1 & 0 & 1 & 1 & 0 & 0 & 0 \\
\hline Steep slope & 1 & 1 & 1 & 1 & 1 & 1 & 1 & 1 & 1 & 1 & 1 & 1 & 1 & 1 & 1 & 1 & 0 & 0 & $\overline{0}$ & $\overline{0}$ & $\dot{0}$ \\
\hline $\begin{array}{l}\text { Presence of large rocks (often }> \\
1 \mathrm{~m} \text { in length) with vertical facies }\end{array}$ & 1 & 1 & 1 & 1 & 1 & 1 & 1 & 1 & 1 & 1 & 1 & 1 & 1 & 1 & 1 & 1 & 0 & 0 & 0 & 0 & 0 \\
\hline No tree stratum $>2 \mathrm{~m}$ & 1 & 1 & 1 & 1 & 1 & 1 & 1 & 1 & 1 & 1 & 1 & 1 & 1 & 1 & 1 & 1 & 1 & 1 & 0 & 1 & 1 \\
\hline $\begin{array}{l}\text { Grassland with a diversity of } \\
\text { herbs and shrubs }\end{array}$ & 1 & 1 & 1 & 1 & 1 & 1 & 1 & 1 & 1 & 1 & 1 & 1 & 1 & 1 & 1 & 1 & 1 & 1 & 1 & 1 & 1 \\
\hline $\begin{array}{l}\text { Clutia pulchella } \\
\text { between } 2-14 / 25 \mathrm{~m}^{2}\end{array}$ & 1 & 1 & 1 & 1 & 1 & 1 & 1 & 1 & 1 & 1 & 1 & 1 & 1 & 1 & 1 & 1 & 1 & 1 & 1 & 0 & 0 \\
\hline $\begin{array}{l}\text { Stands of bracken, } \\
\text { Pteridium aquilinum }\end{array}$ & 0 & 0 & 0 & 1 & 1 & 1 & 0 & 0 & 0 & 0 & 0 & 0 & 0 & 0 & 0 & $\overline{0}$ & 0 & $\overline{0}$ & $\overline{0}$ & 0 & 0 \\
\hline
\end{tabular}


indicating that the butterfly only occurs in a certain climate regime (Table 2). The butterfly colonies are only found at locations that are covered with large rocks. These rocks seem to be a habitat requirement for the host plant. In addition, steep upper midslopes seem to be essential even on the most local scale (the butterfly does not breed on the terraces). Only the cool southern-facing slopes are chosen by the colonies of the butterflies for reasons which are not yet clear. This small-scale study showed that Chrysoritis aureus is indeed specific on a very local scale with regard to its choice of habitat.

Two related sub-communities with different floristic compositions, but similar vegetation structures were recorded as habitats of Chrysoritis aureus. The habitats of Chrysoritis aureus are dominated by grass species though a high forb diversity was observed. Many of these forbs are perennials that can survive fire. These include Clutia pulchella (the host plant) as well as nectar plants for the adult butterfly, such as Tetraselago wilmsii (Species-group D; Table 3). Despite dense stands of trees or shrubs observed to be growing on the same hill of each of the localities studied, the tree component was almost absent where Chrysoritis aureus is present. Since dense and relatively diverse communities of trees and shrubs are particular to the Rocky Highveld Grassland (Bredenkamp \& Van Rooyen 1996)-compared to other types of grassland-it is believed that the more open vegetation noted at the habitats of Chrysoritis aureus are important for conservation management. Fire and frost are two factors that probably play a key role in the maintenance of a suitable habitat for Chrysoritis aureus since both are needed to maintain the grasslands in these Rocky Highveld Grassland areas.

Acocks (1988) interpreted Bankenveld (now included in the Rocky Highveld Grassland) as a fire-maintained false grassland which would develop into savanna if fire was excluded. The vegetation of the Suikerbosrand Nature Reserve that was studied by Bredenkamp \& Theron (1978, 1980) provides a further context within which the veg- etation studies at the Chrysoritis aureus habitat at Suikerbosrand could be seen. Bredenkamp \& Theron (1978) described a Protea caffra-Helichrysum setosum savanna community that is also found on rocky steep southern slopes of the Witwatersrand Supergroup in the Suikerbosrand Nature Reserve. A Protea caffra-Clutia pulchella variant was also distinguished by Bredenkamp \& Theron (1978). An open tree stratum was observed in this variant consisting of a number of trees of which Protea caffra was the most conspicuous (Bredenkamp \& Theron 1978). No Chrysoritis aureus were found in the past (including surveys by members of the Lepidopterists' Society) in the vegetation where Protea caffra individuals are an important component of the vegetation. The absence of Protea caffra and any tree layer at all the sites where Chrysoritis aureus occur is therefore a confirmation of the more open nature of the vegetation in the habitats of the butterfly. These open patches in the locations where Clutia pulchella occur and which are concomitant with an absence of Protea caffra seems to be localised, and perhaps marginal. A larger study area should reveal more information about the significance of the absence of a tree stratum at the sites where Chrysoritis aureus occurs. Fire may play an important role in the regulation of the Chrysoritis aureus habitats. The timing and intensity of fires in the vegetation among the rocky ridges where Clutia pulchella grow should be continually monitored to promote the survival of Chrysoritis aureus.

Frost is also mentioned in literature to play an important role in the distribution of the woody elements in the Rocky Highveld Grassland, as mentioned by Bredenkamp \& Van Rooyen (1996). Grassland vegetation in the Rocky Highveld Grassland is restricted to exposed cooler sites (Bredenkamp \& Van Rooyen 1996). All the habitats of Chrysoritis aureus are at exposed sites below the summit of these hills (on the upper slopes). Chrysoritis aureus have not been found in any of the kloofs in these areas where large numbers of Clutia pulchella were observed, though unfortunately no sample plots were placed there for quantitative comparisons. 
Since Chrysoritis aureus is also associated with an ant species, Crematogaster liengmei, the structure of the vegetation and the role of factors such as fire may be part of the specific habitat requirements of the ants. The present ant community studies may reveal more insight into these habitat requirements, especially against the background of the vegetation analysis provided in this study.

The open nature of the vegetation at the habitats of Chrysoritis aureus has further implications for the control of invasive plants in these areas. Cover-abundances of the Pteridium aquilinum (bracken fern) stands at the Chrysoritis aureus habitat at the Suikerbosrand Nature Reserve should be monitored, since the bracken fern can be regarded as invasive. This habitat occurs at the border fence of the reserve and is regularly burnt as part of a fire break. The best method to control bracken, if deemed necessary, is by cutting (Marrs et al. 1998). Bracken ferns possess a number of underground rhizomes and are well adapted to fire. Oinonen (1967) found that bracken established best from spores that are present on sites that had been burnt.

Another consideration for the management at all the sites is to prevent bush encroachment and the establishment of any exotic tree species, since this will clearly destroy the localised habitats. Continued control of the invasive Acacia mearnsii, which is a declared invader (with commercial value) (Bromilow 2001; Henderson 2001) at the Alice Glockner Nature Reserve, is imperative since this will save the butterfly habitats from a possible catastrophe in future.

\section{Conclusion}

The vegetation at the three localities where Chrysoritis aureus is present, is similar with regard to general structure, but there are differences in species composition on the subcommunity level. A remarkable coincidence in the Malanskraal habitats, being a different sub-community, is that the Clutia pulchella individuals collected there also differ markedly from individuals from the localities at Alice Glockner Nature Reserve and the Suikerbosrand Nature Reserve. The Malanskraal habitat is also on the Ventersdorp Supergroup in contrast with the habitats at the Alice Glockner Nature Reserve and Suikerbosrand Nature Reserve. An hypothesis to be tested is that the genetic make-up of the Chrysoritis aureus populations at the three localities are different, since they seem to be adapted to habitats that differ to some extent. These findings would be valuable for the conservation of Chrysoritis aureus if translocation of the butterfly or restoration of habitats are considered. Securing corridors that link habitats is an aspect that deserves attention, especially in the sense that these must include adequate nectar sources.

The value of a phytosociological survey to support conservation research and management strategies for a threatened butterfly are confirmed by this study and by Deutschländer \& Bredenkamp (1999). The vegetation structure would be an important aspect to consider in the management of areas where Chrysoritis aureus occurs and could even be studied in more detail on a larger scale. Due to the open nature of the vegetation and localised distribution of the habitats of Chrysoritis aureus the application of firemanagement should be applied with care while bush encroachment, especially of any tree layer, should be avoided. Alien vegetation in these areas should also be monitored since the establishment of exotic tree species will destroy the habitats of Chrysoritis aureus.

Further research priorities that were identified, include a study of ant communities locally at the habitats of Chrysoritis aureus. To study the nectar sources of Chrysoritis aureus in more detail a larger study area than the one used here, would be needed since it seems that the butterfly occasionally wanders of from its central breeding ground in search of nectar. Larger sample plots $\left(100 \mathrm{~m}^{2}\right)$ and a larger study area should therefore be included for such studies. For the studies on the optimal density of the host 
plant, aspects other than southern aspects, should also be included.

It is hoped that more and diverse research on the rare and localised butterflies of Africa can be continued since it is believed that a holistic approach in the research will lead to more discoveries with regard to the intrigued habitat requirements of these organisms. It is recommended that the various sites where Chrysoritis aureus occurs, should receive priority for conservation purposes. In the light of the variation in the habitats of Chrysoritis aureus encountered during this study, the securing of one habitat for the conservation of a local habitat-specific butterfly might be a risk. The implications for butterflies such as Orachrysops niobe (Brenton Blue), where only one locality is known, is that such butterflies might be in a precarious situation even if the remaining habitat is conserved, since the meta-population dynamics may be limited.

The threat of urbanisation to the conservation of the Rocky Highveld Grassland in general is mentioned by Bredenkamp \& Van Rooyen (1996) and it seems to be prophetic regarding the conservation of Chrysoritis aureus. Rocky Highveld Grassland is poorly conserved (Bredenkamp \& Van Rooyen 1996) and if the number and extent of conservation areas are considered the development and conservation of the Alice Glockner Nature Reserve will prove to be an important asset for biodiversity conservation and ecotourism in South Africa.

\section{Acknowledgements}

We wish to thank Henning \& Roos CC as well as Michelle Pfab and Marianne Forsyth (Gauteng Department of Agriculture, Conservation and Environment) for their professional support and assistance. This research would not have been possible if it had not been for the financial support of the Gauteng Department of Agriculture, Conservation and Environment, via Roos \& Henning CC.

\section{References}

ACOCKS, J.P.H. 1988. Veld types of South Africa. Memoirs of the botanical Survey of South Africa No. 57.

Arnold, T.H. \& B.C. DE WeT (eds). 1993. Plants of Southern Africa: names and distribution. Memoirs of the botanical Survey of South Africa No. 62.

Bezuidenhout, H., H.C. Biggs \& G.J. BredenKAmP. 1996. A process supported by the utility BBPC for analysing Braun-Blanquet data on a personal computor. Koedoe 39(1): 107-112.

BredenKAmP, G.J. \& G.K. Theron. 1978. A synecological account of the Suikerbosrand Nature Reserve I. The phytosociology of the Witwatersrand Geological System. Bothalia 12(3): 513529.

BredenKamp, G.J. \& G.K. Theron. 1980. A synecological account of the Suikerbosrand Nature Reserve II. The phytosociology of the Ventersdorp Geological System. Bothalia 13(1\&2): 199-216.

BREDENKAmp, G.J. \& N. Van RoOyen. 1996. Rocky Highveld Grassland. In: Low, A.B. \& A.G. Rebelo (eds.). Vegetation of South Africa, Lesotho and Swaziland. Pretoria: Department of Environmental Affairs \& Tourism.

Bromilow, C. 2001. Problem plants of South Africa. Pretoria: Briza.

Cottrell, C.B. 1984. Aphytophagy in butterflies: its relationships to myrmecophily. Zoological Journal of the Linnean Society 79: 1-57.

DEUTSCHLÄNDER, M.S. \& C.J. BREDENKAMP. 1999. Importance of vegetation analysis in the conservation management of the endangered butterfly Aloeides dentatis subsp. dentatis (Swierstra) (Lepidoptera: Lycaenidae). Koedoe 42(2): 1-12.

DE WeT, K. 1987. Die bewaring van die skoenlappers van die genus Charaxes en van Erikssonia acraeina in die Transvaal. Proceedings of the first Lepidoptera conservation Symposium, Roodepoort: Lepidopterists' Society of southern Africa: 5-7.

Du ToIT, A.C. 1954. The geology of South Africa Edinburgh: Oliver \& Boyd.

EDWARDS, D. 1983. A broad-scale structural classification of vegetation for practical purposes. Bothalia 14(3): 705-712.

Heath, A. 1997. A review of African genera of the tribe Aphnaeini (Lepidoptera: Lycaenidae). Metamorphosis: Occasional Supplement No. 2: $1-60$.

Heath, A. 2001. New synonymies and taxonomic notes on the genus Chrysoritis Butler (Lepidoptera: Lycaenidae). Metamorphosis 12 (3): 85-98.

HENDERSON, L. 2001. Alien weeds and invasive plants: a complete guide to declared weeds and invaders in South Africa. Cape Town: Agricul- 
tural Research Council. (Plant Protection Research Institute Handbook No. 12.)

Henning, G.A. 1986a. Research at Suikerbosrand Nature Reserve, 7 September 1986. Transvaal Nature Conservation. Unpublished report.

HENNING, G.A. 1986b. Research at Suikerbosrand Nature Reserve, 2 December 1986. Transvaal Nature Conservation. Unpublished report

HenNING, G.A. 1987. Research at Suikerbosrand Nature Reserve, 1st quarter 1987. Transvaal Nature Conservation. Unpublished report.

HenNING, G.A. \& S.F. HenNING. 1995. Updating the status of South African Red Data Butterfly species. Metamorphosis 6(2): 96-98.

HenNING, S.F. 1983. Biological groups within the Lycaenidae (Lepidoptera). Journal of the Entomological Society of southern Africa 46(1): 6585.

HenNING, S.F. 1987a. Myrmecophilous Lycaenidae (or how ants help butterflies). South African Journal of Science 83: 8-9.

HenNing, S.F. 1987b. Outline of Lepidoptera conservation with special reference to ant associated Lycaenidae. Proceedings of the first Lepidoptera conservation Symposium, Roodepoort: Lepidopterists' Society of southern Africa: 5-7.

Henning, S.F. \& G.A. Henning. 1989. South African red data book: butterflies. Pretoria: Council for Scientific and Industrial Research, National Scientific Programmes Unit. (South African National Scientific Programmes report; no. 158.)

HiLl, M.O. 1979a. TWINSPAN. A Fortran programme for arranging multivariate data in an ordered two way table by classification of individuals and attributes. Ithaca, New York: Cornell University.

Hill, M.O. 1979b. Decorana. A Fortran programme for detrended correspondence analysis and reciprocal averaging. Ithaca, New York: Cornell University.

KudRnA, O. 1995. Conservation of butterflies in central Europe. Pp. 248 - 257. In: Pullin, A.S. (ed.). Ecology and conservation of butterflies. London: Chapman \& Hall.

LARSEN, T.B. 1995. Butterfly biodiversity and conservation in the Afrotropical region. Pp. 290303. In: Pullin, A.S. (ed.). Ecology and conservation of butterflies. London: Chapman \& Hall.

Low, A.B. \& A.G. Rebelo. (eds.). 1996. Vegetation of South Africa, Lesotho and Swaziland. Pretoria: Department of Environmental Affairs \& Tourism.

MarRs, R.H., S.W. Johnson \& M.G. Le Duc. 1998. Control of bracken and restoration of heathland VII. The response of bracken rhizomes to 18 years of continued bracken control or 6 years of control followed by recovery. Journal of Applied Ecology 35: 748-757.
Mueller-Dombois, D. \& H. Ellenberg. 1974. Aims and methods of vegetation ecology. New York: Wiley.

Munguira, M.L. 1995. Conservation of butterfy habitats and diversity in European Mediterranean countries. Pp. 277- 289. In PULlin, A.S. (ed.). Ecology and conservation of butterflies. London: Chapman \& Hall.

New, T.R. 1995. Butterfly conservation in Australasia - an emerging awareness and an increasing need. Pp. 304 - 315. In Pullin, A.S. (ed.). Ecology and conservation of butterflies. London: Chapman \& Hall.

OATES, M.R. 1995. Butterfly conservation within the management of grassland habitats. Pp. 98-112. In: Pullin, A.S. (ed.). Ecology and conservation of butterflies. London: Chapman \& Hall.

O'Dwyer, C. \& P.M. ATtiwiLl. 2000. Restoration of a native grassland as habitat for the Golden Sun Moth Synemon plana Walker (Lepidoptera: Castniidae) at Mount Piper, Australia. Restoration Ecology 8 (2):170-174.

OINONEN, E. 1967. Sporal regeneration of bracken (Pteridium aquilinum) (L. Kuhn.) in Finland in the light of the dimensions and age of its clones. Acta Forestalia Fennica 83(2): 1-51.

Opler, P.A. 1995. Conservation and management of butterfly diversity in North America. Pp. 316 - 324. In: Pullin, A.S. (ed.). Ecology and conservation of butterflies. London: Chapman \& Hall.

Owen-Johnston, N.K. 1991. Thoughts and observations on the genus Poecilmitis Butler (Lepidoptera: Lycaenidae) in the Transvaal. Metamorphosis 2(3): 49-50.

Prain, D. 1925. Cluytia. Pp. 427-456 In: ThiseltonDyer, W.T. (ed.). Flora Capensis: Part III. London: Reeve.

Pringle, E.L., G.A. Henning \& J.B. Ball (eds.). 1994. Pennington's Butterflies of Southern Africa. Kaapstad: Struik Winchester.

PULLIN, A.S. ed. Ecology and conservation of butterflies. London: Chapman \& Hall.

Pullin, A.S., I.F.G. Mclean \& M.R. WebB. 1995. Ecology and conservation of Lycaena dispar: British and European perspectives. Pp. 150-164. In: Pullin, A.S. (ed.). Ecology and conservation of butterflies. London: Chapman \& Hall.

Retief, E. \& P.P.J. Herman. 1997. Plants of the northern provinces of South Africa: keys and diagnostic characters. Pretoria: National Botanical Institute.

Roos, P. \& G.A. Henning. 2000. The Heidelberg Copper Butterfly. African Wildlife 54(2): 24 -27.

Rutherford, M.C. \& R.H. WestFall. 1994. Biomes of southern Africa: an objective categorization. Memoirs of the botanical Survey of South Africa No. 63. 
Thomas, C.D. 1995. Ecology and conservation of butterfly metapopulations in the fragmented British landscape. Pp. 46-64. In: Pullin, A.S. (ed.). Ecology and conservation of butterflies. London: Chapman \& Hall.

Van Oudtshoorn, F.P., W.S.W., Trollope, D.M. SCOTNEY \& P.J. MCPHEE. 1991. Guide to the grasses of South Africa. Pretoria: Briza.

Von BreitenBach, F. 1990. National list of indigenous trees. Pretoria: Dendrological Foundation.
Von Breitenbach, J., B. De Winter, R. Poynton, E. VAN DER BERG, B. VAN WYK \& E. VAN WYK. 2001. Pocket list of southern African indigenous trees: including selected shrubs and woody climbers. Pretoria: Briza.

WARREN, M.S. 1995. Managing local microclimates for the high brown fritillary, Argynnis adipe. Pp. 198-210. In: Pullin, A.S. (ed.). Ecology and conservation of butterflies. London: Chapman \& Hall. 